\title{
ORIGINAL
}

\section{Impact of bronchial colonization with Candida spp. on the risk of bacterial ventilator-associated pneumonia in the ICU: the FUNGIBACT prospective cohort study}

\author{
Jean-Francois Timsit ${ }^{1,2^{*}}$ C, Carole Schwebel ${ }^{3}$, Lenka Styfalova ${ }^{4}$, Muriel Cornet ${ }^{5,6}$, Philippe Poirier $^{7}$, \\ Christiane Forrestier ${ }^{8}$, Stéphane Ruckly, ${ }^{2,4}$, Marie-Christine Jacob ${ }^{9,10}$ and Bertrand Souweine ${ }^{11}$
}

(C) 2019 Springer-Verlag GmbH Germany, part of Springer Nature

\begin{abstract}
Introduction: Respiratory tract Candida spp. colonization is associated with more frequent bacterial ventilatorassociated pneumonia (VAP). However, this colonization could be causally related to VAP or simply reflect the immune paralysis associated with multiple organ failure.

Objective: To prospectively evaluate the relationship between Candida spp. colonization and bacterial VAP in mechanically ventilated patients with multiple organ failure.

Inclusion: Patients receiving mechanical ventilation for $>4$ days and presenting multiple organ failure were included. Tracheal colonization with Candida spp. was evaluated at inclusion (day 0, D0) and every 4 days until extubation. Quantitative proximal and tracheal cultures were performed at each VAP episode. Monocyte human leukocyte antigen-DR isotype (mHLA-DR) expression and the ratio of polymononuclear leukocytes to lymphocytes were used to evaluate immunoparalysis at D0 and D7. The relationship between fungal colonization and VAP was modelled using cause-specific models for repeated events with adjustment for time-dependent confounders and immune factors.

Results: A total of 213 patients, with a median age of 64 , simplified acute physiology score II (SAPS II) score 55 and sequential organ failure assessment (SOFA) score 10, mainly admitted for medical reasons $(n=197,92 \%)$, were enrolled in 2012-2015. The median ICU stay was 24 days and the mortality rate was 32\% (69 cases). Median mHLA-DR was 5916 Ab-bound/cell [3863-8934]; median lymphocyte count, 0.9Giga/L [0.6-1.3]; neutrophil-to-lymphocyte ratio, 10.9 [6.5-19.7]. Overall, 146 cases (68.5\%) had tracheal colonization with Candida spp. An episode of VAP occurred (either for the first or only time) in 62 (29.1\%) cases 5.5 days (median) after D0; a second episode occurred in 12 (5.6\%) cases, 15.5 days (median) after D0. After adjustment, bronchial colonization with Candida was not associated with VAP [adjusted cause-specific hazard ratio $=0.98(0.59-1.65), p=0.95$ ].
\end{abstract}

Conclusion: In patients with mechanical ventilation for more than 4 days and multiple organ failure, bronchial colonization with Candida spp. was not associated with VAP, even after adjustment for immune function.

*Correspondence: jean-francois.timsit@bch.aphp.fr

${ }^{1}$ Medical and Infectious Diseases ICU, Bichat-Claude Bernard Hospital, APHP, Paris, France

Full author information is available at the end of the article 
Keywords: Sepsis, Candida, Immunoparalysis, Ventilator-associated pneumonia, Pseudomonas aeruginosa,

Staphylococcus aureus

\section{Introduction}

Candida spp. colonization in bronchial samples is common in mechanically ventilated ICU patients. It occurs in about $30 \%$ of patients receiving mechanical ventilation (MV) for more than $48 \mathrm{~h}$ and in $50 \%$ of those with a clinical suspicion of ventilator-associated pneumonia (VAP) [1]. Recovery of Candida spp. from the respiratory tract is associated with increased duration of $\mathrm{MV}$ and of ICU and hospital stay, and with a worse outcome [2-5].

Other than in deeply immunosuppressed subjects, who may develop true fungal pneumonia, a lower respiratory tract yielding Candida spp. isolates should not usually be considered a marker of lung infection [6-10].

However, several clinical data suggest that Candida spp. airway colonization may play a significant role in the development of bacterial pneumonia. In a cohort study, Azoulay et al. found that Candida spp. bronchial colonization increased the risk of Pseudomonas aeruginosa pneumonia [11]. A single-center retrospective case-control study has shown that antifungal therapy administered to patients with Candida spp. airway colonization could prevent $P$. aeruginosa VAP [12].

However, another observational trial that compared colonized patients who received aerosolized amphotericin $\mathrm{B}$ with other colonized patients failed to identify any impact on VAP risk, even though the treatment produced a significant decrease in the bronchial colonization [13].

In addition, in a randomized, double-blind, placebocontrolled multicenter study, an empirical anti-fungal strategy in patients with a clinical diagnosis of VAP and Candida spp. airway colonization failed to improve either inflammatory reaction or patient outcome [14]. Moreover, empirical therapy with micafungin did not have any impact on the risk of VAP [10] in a recent randomized, double-blind, placebo-controlled study in multiple colonized non-immunocompromised mechanically ventilated patients with multiple organ failure.

The discrepancies observed between these studies could be related, in part, to the contribution of the host immune response. Cellular immunity is of major importance for effective clearance of fungi and bacteria.

Critical illness can induce a state of profound immune dysfunction with severe monocyte and lymphocyte dysfunction [15]. Reduced expression of the human leukocyte antigen-DR isotype (HLA-DR) on monocytes is

\section{Take-home message}

In a prospective study of mechanically ventilated patients, bronchial candida colonization was frequent and did not impact the risk of ventilator-associated pneumonia, even after adjustment for immune status

a reliable biomarker for assessing the immune status of critically ill patients [16].

The temporal relationship between airway Candida spp. colonization and subsequent bacterial VAP is quite complex. Both immunoparalysis and Candida spp. airway colonization could promote bacterial VAP depending on their reciprocal interactions. However, Candida spp. airway colonization and VAP onset can also be independent and, for instance, both due to prior antibiotic exposure or to profound immunoparalysis, as observed in patients with a severe acute illness and prolonged ICU length of stay (LOS) $[17,18]$.

In view of these considerations, we conducted a prospective study to assess the role of Candida spp. airway colonization in the development of subsequent lateonset bacterial VAP in patients mechanically ventilated for more than 4 days and presenting with multiple organ failure.

\section{Materials and methods}

We designed a prospective study conducted between 2012 and 2015 in two French medical ICUs (The University Hospitals of Grenoble and Clermont-Ferrand).

\section{Ethics and funding}

The study was sponsored by the University of Grenoble and received grant funding from the French Ministry of Health [ethics committee: ("Comité de Protection des Personnes") CPP South East IV 11-055 August 30th 2011-No. ID RCB 2011-A00767-34; www.clinicaltrials. gov: NCT01770015].

Written informed consent was obtained from all participants or their proxies. In situations of impaired decision-making capacity and absence of surrogates, informed consent was obtained later on from the patient (in compliance with French laws).

\section{Data collected}

Adult patients receiving invasive MV for more than 4 days and with at least one additional organ dysfunction were considered for enrolment. Severely 
immunocompromised patients (i.e. patients with neutropenia, solid organ transplant and bone marrow transplant recipients, patients receiving corticosteroid therapy consisting of $>2 \mathrm{mg} / \mathrm{kg}$ of methylprednisolone or equivalent) and patients on prior antifungal treatment were excluded. Day 0 (D0) was defined as the day of inclusion. Daily monitoring was performed in all patients for signs and symptoms of infection, organ dysfunction and other ICU-acquired complications. Blood samples were drawn at D0 and every 7 days thereafter until ICU discharge, to be used to measure HLA-DR expression on monocytes, as previously described $[15,19]$, and the neutrophil-tolymphocyte ratio $[20,21]$, in order to assess immune function. Endotracheal aspirates were also obtained at D0 and every 7 days thereafter to identify Candida spp. airway colonization. Candida sp. identification was performed as previously described [22]. Briefly, specimens were inoculated onto CAN2 chromogenic isolation plates and/or into Sabouraud chloramphenicol tubes (bioMérieux, Lyon, France) and incubated for $3-6$ days at $35^{\circ} \mathrm{C}$. The following rapid tests were used for identification: rapid assimilation or agglutination tests (Glabrata RTT, Bichro-Latex Albicans and Krusei-Color; Fumouze Diagnostics, Levallois-Perret, France) and api-ID32C (bioMérieux, Lyon, France).

The primary outcome was the occurrence of late-onset VAP. VAP was defined by the presence of clinical signs and symptoms of VAP, and either a broncho-alveolar lavage (BAL) culture yielding at least $10^{4} \mathrm{cfu} / \mathrm{ml}$ or a quantitative tracheal aspirate culture yielding at least $10^{5} \mathrm{cfu} /$ $\mathrm{ml}$. All episodes of VAP were taken into account. Lateonset $P$. aeruginosa and $S$. aureus VAP were secondary outcomes (Fig. E1). The VAP prevention policy was similar between ICUs and is described elsewhere [23]. Subglottic aspiration was not used as routine practice.

\section{Statistical analysis}

A sample size of 550 patients was originally planned in order to detect a $20-33.3 \%$ increase in the incidence of late-onset bacterial VAP with an odds ratio of 2, on the basis of an expected 25\% Candida airway colonization rate. After inclusion of 100 patients, the observed airway Candida colonization rate was higher than $45 \%$, and so the sample size was revised and decreased to 230 patients to maintain an acceptable power of $80 \%$ with the same hypothesis.

In the statistical analysis, ICU discharge or death and late-onset VAP were considered as competing events until D60. Models for competing events were therefore used to assess the association between Candida airway colonization and subsequent late-onset VAP and expressed as cause-specific hazard ratio (CSHR). Models were adjusted for the risk factors of late-onset VAP (see Table E1) defined by the univariate models, and for neutrophil-to-lymphocyte ratio and monocyte HLA-DR (mHLA-DR). Candida airway colonization and impaired immune function were fitted as time-dependent covariables. The direct effect of Candida airway colonization on the risk of VAP was estimated by CSHR. We used SAS 9.4 (Sas Institute, NC, USA) and R 3.0.2 (Vienna, Austria) for all the statistical analyses.

\section{Results}

The study involved 230 patients. Informed consent was withheld by 17 of them. Therefore, 213 patients were included in the analyses (Fig. 1). Their characteristics are shown in Table 1 . The patients were mainly males, admitted for medical reasons, with high simplified acute physiology score II (SAPS II) and sequential organ failure assessment (SOFA) scores, prolonged ICU LOS, and high ICU- and 60-day mortality.

At inclusion, the population was immunoparalyzed, as demonstrated by the low median level of mHLA-DR, the high percentage of patients with mHLA-DR levels of less than 8000 monoclonal antibodies per cell $(\mathrm{AB} / \mathrm{c})$, the low median lymphocyte counts and the high median neutrophil-to-lymphocyte ratio (Fig. 2). Candida spp. airway colonization was observed in 146 patients (98 at D0 and 48 during the follow-up period; Table 2).

Of the 213 patients, $62(29.1 \%)$ developed at least one episode of VAP (Table 1). This first or only episode of VAP occurred at a median of 5.5 days after D0, while in 12 patients (5.6\%), a second episode occurred at a median of 15.5 days after D0. Candida spp. airway colonization was present at D0 in 27 of the 62 patients with VAP. VAP was due to Staphylococcus aureus in 13 patients, including 8 with Candida airway colonization at D0, and due to $P$. aeruginosa in 17 patients, including 5 with Candida airway colonization at D0 (Table 2 and Fig. E2).

The distribution of Candida species isolated from the lower respiratory tract samples and the distribution of micro-organisms causative of VAP are shown in Table 1 and 2. C. albicans accounted for $71 \%$ of Candida airway colonization at D0. This species was recovered from the lower respiratory tract prior to VAP in $26 / 34$ (76\%) patients, and it was also recovered in 71/103 (69\%) patients who did not develop subsequent VAP.

In the univariate analysis, the cumulative risk of the first episode of late-onset VAP did not differ between patients with or without bronchial Candida colonization at D0 (Fig. 3). In the multivariate cause-specific models, after adjustment for VAP risk factors (Table E1) and time-dependent co-factors, Candida airway colonization had no impact on the CSHR of late-onset VAP, even after adjustment for immunoparalysis status (Table 3). In sensitivity analysis, using the same models, Candida airway 


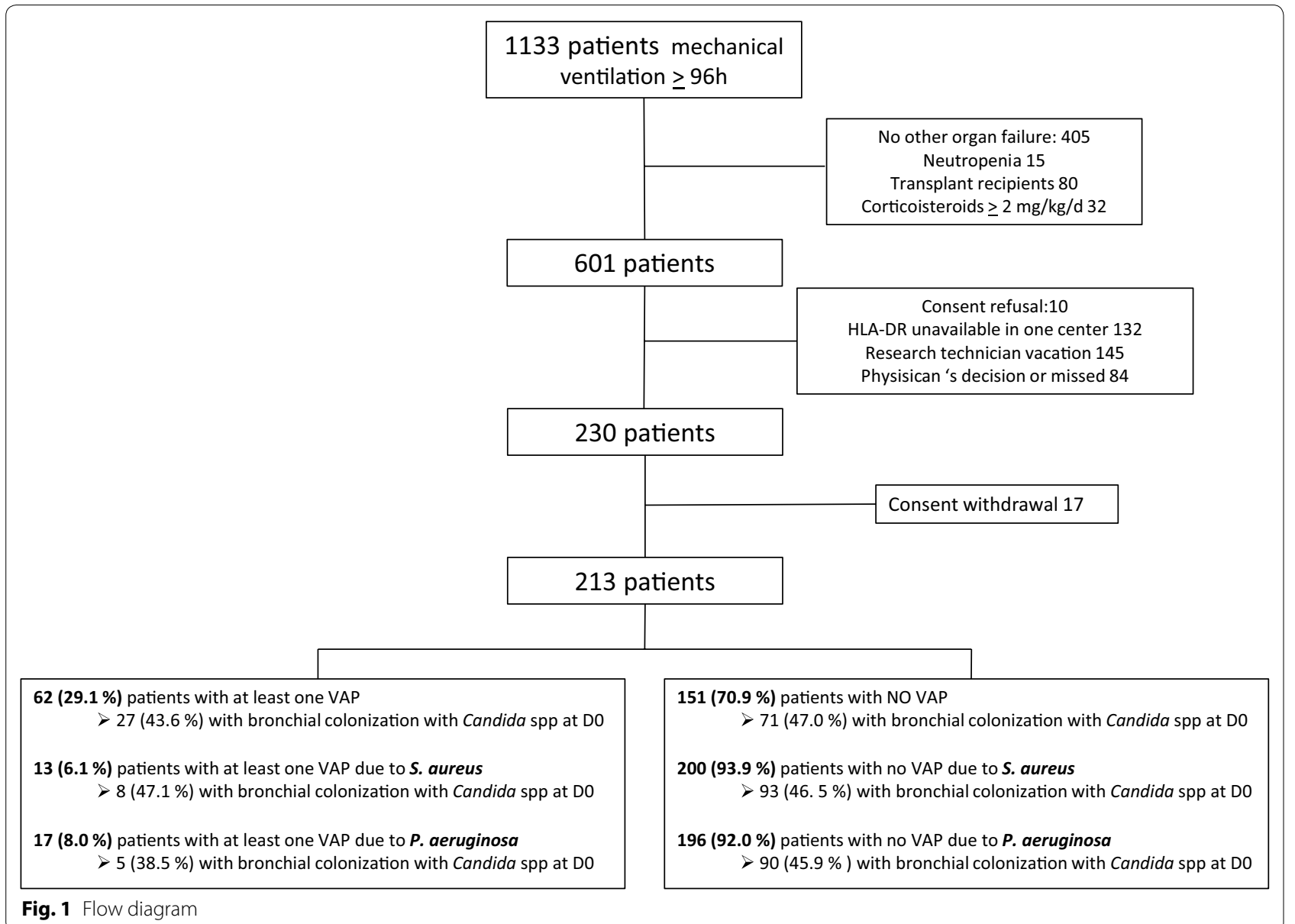

colonization had no impact on the CSHR of late-onset P. aeruginosa VAP (Table E2) or Staphylococcus aureus VAP (Table E3).

\section{Discussion}

In a prospective, two-center cohort study of long-term mechanically ventilated patients, bronchial colonization with Candida spp. was not found to be a risk factor either for bacterial VAP or for death. These findings remained similar after adjustment for host immune status reflected by HLA-DR and ratio of neutrophils to lymphocytes.

The immune response, both innate and adaptive, is important for controlling Candida spp. colonization and infection [24]. Blood monocytes and tissue macrophages recognize pathogen-associated molecular patterns like fungal cell wall components. Antigen presentation and subsequent cytokine secretion lead to T-helper lymphocyte activation and a secondary adaptive immune response [25]. The expression of cell surface markers such as mHLA-DR reflects the activation of monocytes and immune function. Accordingly, low mHLA-DR expression has been described as a robust marker of immune dysfunction [26] and of outcome following septic shock or trauma. Furthermore, mHLA-DR expression lower than $8000 \mathrm{AB} / \mathrm{c}$ has been associated with an increased risk of hospital-acquired infection following septic shock $[15,26]$ or multiple trauma [27]. Apoptotic cell death represents the major mechanism triggering sepsis-induced lymphocyte anergy/dysfunctions. After sepsis and severe trauma, immunoparalysis has been shown to be associated with a marked decrease in circulating lymphocyte numbers, in correlation with the development of nosocomial infections $[21,28]$ and altered patient prognosis.

Therefore, markers of immune paralysis should be taken into account to evaluate the possible link between Candida spp. colonization or infection and nosocomial infections such as VAP.

Findings on the interactions between Candida spp. and bacterial pathogens are controversial. More than 10 years ago, in a prospective cohort study, we reported that Candida spp. airway colonization was an independent risk factor for the development of $P$. aeruginosa VAP ( 9 vs. $4.8 \%$ in non-colonized patients, $p=0.048$ ) [29]. Similarly, a single-center retrospective case-control study showed 


\section{Table 1 Characteristics of the patients enrolled}

\begin{tabular}{|c|c|c|c|c|}
\hline & $\begin{array}{l}\text { All patients } \\
(n=213)\end{array}$ & $\begin{array}{l}\text { Patients without Can- } \\
\text { dida airway coloniza- } \\
\text { tion } \\
(n=67)\end{array}$ & $\begin{array}{l}\text { Patients with Candida } \\
\text { airway colonization } \\
\text { at inclusion } \\
(n=98)\end{array}$ & $\begin{array}{l}\text { Patients with Candida airway } \\
\text { colonization during the follow-up } \\
(n=48)\end{array}$ \\
\hline Males $(n, \%)$ & $144(68)$ & $46(68.7)$ & $66(67.3)$ & $32(66.7)$ \\
\hline Age, years (median [IQR]) & $64[55 ; 72]$ & $65.1[57.9 ; 72.4]$ & $64.6[55.4 ; 74.1]$ & $63.5[51.1 ; 69.3]$ \\
\hline $\begin{array}{l}\text { Chronic disease (medical history) } \\
(n, \%)\end{array}$ & $139(65.3)$ & $42(62.7)$ & $65(66.3)$ & $32(66.7)$ \\
\hline Hepatic chronic disease (n, \%) & $22(10.3)$ & $6(9)$ & $13(13.3)$ & $3(6.3)$ \\
\hline Cardiac chronic disease $(n, \%)$ & $56(26.3)$ & $15(22.4)$ & $28(28.6)$ & $13(27.1)$ \\
\hline Respiratory chronic disease $(n, \%)$ & $34(16)$ & $12(17.9)$ & $14(14.3)$ & $8(16.7)$ \\
\hline Renal chronic disease $(n, \%)$ & $14(6.6)$ & $6(9)$ & $7(7.1)$ & $1(2.1)$ \\
\hline Immunodepression ${ }^{\mathrm{a}(n, \%)}$ & $22(10.3)$ & $9(13.4)$ & $6(6.1)$ & $7(14.6)$ \\
\hline Medical admission $(n, \%)$ & $197(92)$ & $64(95.5)$ & $88(89.8)$ & $45(93.8)$ \\
\hline $\begin{array}{l}\text { Admission SAPS II score (median } \\
{\left[{ }^{[Q R R]}\right)}\end{array}$ & $55[43 ; 66]$ & $56[45 ; 68]$ & $54.5[43 ; 66]$ & $54.5[38 ; 66]$ \\
\hline \multicolumn{5}{|l|}{ Cause of admission } \\
\hline $\begin{array}{l}\text { Shock or multiple organ failure } \\
\quad(n, \%)\end{array}$ & $73(34.3)$ & $24(35.8)$ & $32(32.7)$ & $17(35.4)$ \\
\hline Coma $(n, \%)$ & $30(14.1)$ & $9(13.4)$ & $14(14.3)$ & $7(14.6)$ \\
\hline Respiratory distress $(n, \%)$ & $91(42.7)$ & $30(44.8)$ & $43(43.9)$ & $18(37.5)$ \\
\hline Other $(n, \%)$ & $19(8.9)$ & $4(6)$ & $9(9.2)$ & $6(12.5)$ \\
\hline Sepsis on admission ( $n, \%)$ & $97(45.5)$ & $25(37.3)$ & $47(48)$ & $25(52.1)$ \\
\hline SOFA score & $10[7,12]$ & $10[7,13]$ & $10[7,12]$ & $9[7,12]$ \\
\hline Procalcitonin at day 0 ( $\mu \mathrm{g} / \mathrm{L})$ & $1.2[0.2 ; 10.3]$ & $0.9[0.2 ; 10.9]$ & $1.3[0.2 ; 9.7]$ & $1.3[0.2 ; 12.8]$ \\
\hline $\begin{array}{l}\text { mHLA-DR, mAb per cell at day } 0 \\
\text { (median }[I Q R])\end{array}$ & $5916[3863 ; 8934]$ & $5850[3772 ; 8804]$ & $6141[3667 ; 9467]$ & 5995 [4513; 8219] \\
\hline $\begin{array}{l}\mathrm{mHLA}-\mathrm{DR}<8000 \mathrm{mAb} \text { per cell at } \\
\text { day } 0(n, \%)\end{array}$ & $135(68)$ & $45(71.4)$ & $61(65.6)$ & $29(67.4)$ \\
\hline $\begin{array}{l}\text { Lymphocyte count, Giga/L at day } 0 \\
\text { (median }[\mathrm{IQR}])\end{array}$ & $0.9[0.6 ; 1.3]$ & $1[0.5 ; 1.4]$ & $0.8[0.6 ; 1.2]$ & $1[0.7 ; 1.6]$ \\
\hline $\begin{array}{l}\text { Neutrophil-to-lymphocyte ratio at } \\
\text { day } 0 \text { (median }[\mathrm{QQR}])\end{array}$ & $10.9[6.5 ; 197]$ & $9.2[6.4 ; 17.6]$ & $11.9[7.4 ; 22.9]$ & $9.3[6.1 ; 15.4]$ \\
\hline $\begin{array}{l}\text { First episode of late-onset VAP } \\
(n, \%)\end{array}$ & $62(29)$ & $19(28.4)$ & $27(27.6)$ & $16(33.3)$ \\
\hline P. aeruginosa $(n, \%)$ & $15(24)$ & $3(16)$ & $7(26)$ & $5(31)$ \\
\hline S. aureus $(n, \%)$ & $13(21)$ & $4(21)$ & $5(19)$ & $4(25)$ \\
\hline $\begin{array}{l}\text { Other gram-negative bacteria } \\
\quad(n, \%)\end{array}$ & $36(58)$ & $11(58)$ & $16(59)$ & $9(56)$ \\
\hline Other bacteria $(n, \%)$ & $9(15)$ & $3(16)$ & $4(15)$ & $2(13)$ \\
\hline $\begin{array}{l}\text { Second episode of late-onset VAP } \\
(n, \%)\end{array}$ & $12(6)$ & $4(6)$ & $5(5.1)$ & $3(6.3)$ \\
\hline P. aeruginosa $(n, \%)$ & $3(25)$ & $1(25)$ & $1(20)$ & $1(33)$ \\
\hline S. aureus $(n, \%)$ & $1(8)$ & 0 & 0 & $1(33)$ \\
\hline $\begin{array}{l}\text { Other gram-negative bacteria } \\
(n, \%)\end{array}$ & $6(50)$ & $2(50)$ & $3(60)$ & $1(33)$ \\
\hline Other bacteria $(n, \%)$ & $3(25)$ & $1(25)$ & $2(40)$ & 0 \\
\hline $\begin{array}{l}\text { ICU length of stay, days (median } \\
\left.\left[{ }^{[Q R}\right]\right)\end{array}$ & $24[17 ; 36]$ & $23[15 ; 37]$ & $23[16 ; 33]$ & $29.5[20.5 ; 44]$ \\
\hline ICU mortality (n, \%) & $69(32)$ & $28(41.8)$ & $28(28.6)$ & $13(27.1)$ \\
\hline Day 60 mortality $(n, \%)$ & 83 (39) & $31(46.3)$ & $35(35.7)$ & $17(35.4)$ \\
\hline
\end{tabular}

SAPS // simplified acute physiology score II, SOFA sequential organ failure assessment, VAP ventilator-associated pneumonia, $m H L A-D R$ monocyte human leukocyte antigen-DR isotype

a Referred to HIV patients, cancer patients without neutropenia, and patients who received steroids $<2 \mathrm{mg} / \mathrm{kg} / \mathrm{day}$ 

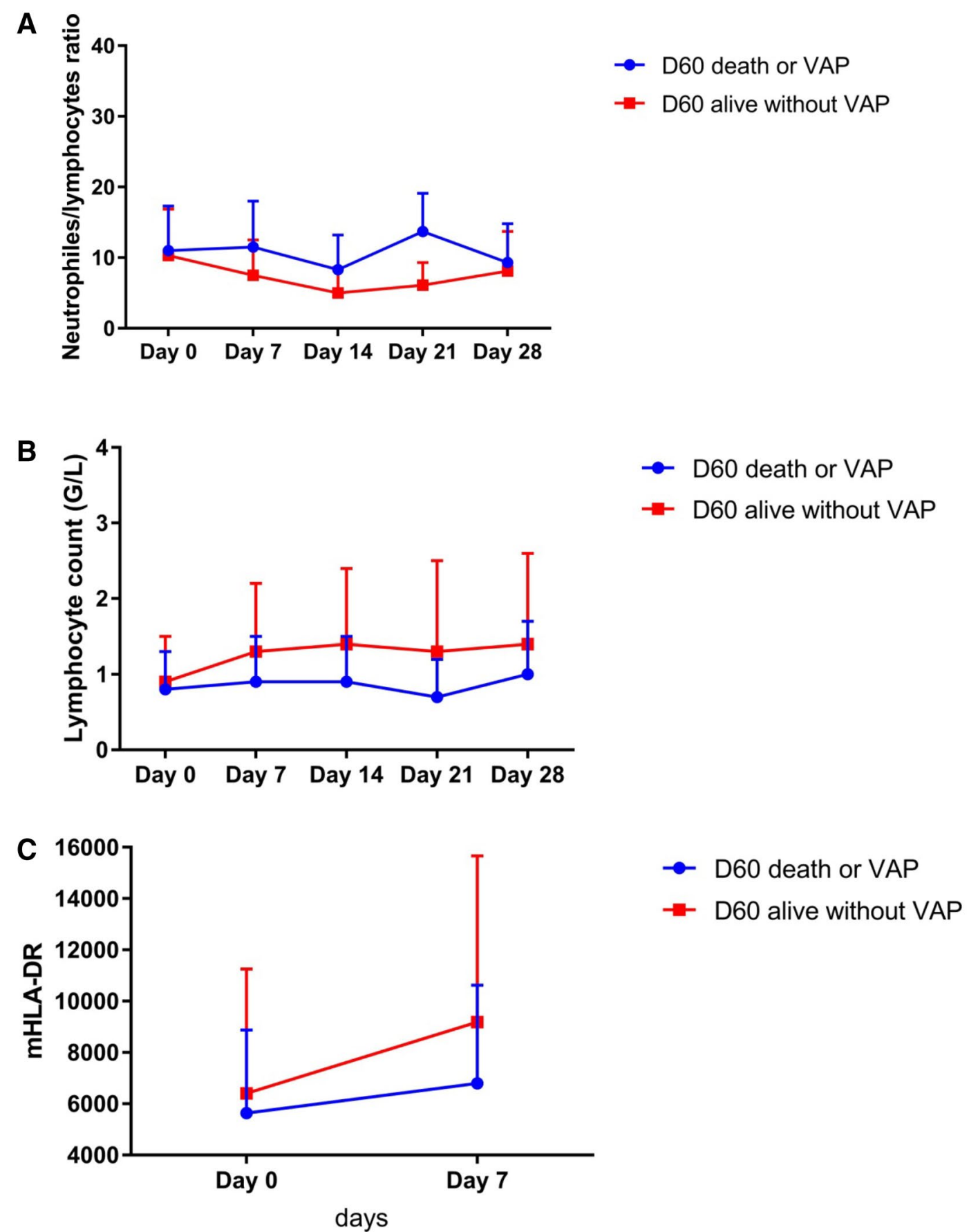

significant, VAP ventilator-associated pneumonia

that antifungal therapy administered to patients with Candida airway colonization could prevent $P$. aeruginosa VAP [12]. More recently, Candida airway colonization was found to be independently associated with Acinetobacter baumannii VAP [30]. In an experimental murine model, the beta-glucan component of the Candida spp. cell wall has been shown to stimulate the release of inflammatory markers and cause alveolar macrophage and neutrophil dysfunction [31]. The interactions between bacterial and fungal species could be greater 
Table 2 Summary of the rates of Candida spp. colonization at inclusion and during the follow-up

\begin{tabular}{|c|c|c|c|c|c|}
\hline Rates of colonization & $\begin{array}{l}\text { Coloniza- } \\
\text { tion at Day } 0 \\
(n=98)\end{array}$ & $\begin{array}{l}\text { Colonization in subjects } \\
\text { without VAP }(n=103)\end{array}$ & $\begin{array}{l}\text { Colonization before the } \\
\text { first episode of VAP }(n=34)\end{array}$ & $\begin{array}{l}\text { Colonization after the first } \\
\text { episode of VAP }(n=9)\end{array}$ & $\begin{array}{l}\text { Total } \\
\text { colonization } \\
(n=146)\end{array}$ \\
\hline Candida spp. & Number (\%) & Number (\%) & Number (\%) & Number (\%) & Number (\%) \\
\hline C. albicans & $70(71.4)$ & $71(68.9)$ & $26(76.5)$ & $6(66.7)$ & $103(70.5)$ \\
\hline C. glabrata & $2(2)$ & $4(3.9)$ & 0 & $2(22.2)$ & $6(4.1)$ \\
\hline C. kefyr & $2(2)$ & $2(1.9)$ & $1(2.9)$ & 0 & $3(2.1)$ \\
\hline C. krusei & $3(3.1)$ & $3(2.9)$ & 0 & 0 & $3(2.1)$ \\
\hline C. lusitaniae & $3(3.1)$ & $3(2.9)$ & 0 & 0 & $3(2.1)$ \\
\hline C. parapsilosis & $8(8.2)$ & $8(7.8)$ & $2(5.9)$ & $1(11.1)$ & $11(7.5)$ \\
\hline C. tropicalis & $5(5.1)$ & $5(4.9)$ & $3(8.8)$ & 0 & $8(5.5)$ \\
\hline Other & $5(5.1)$ & $7(7)$ & $2(5.9)$ & 0 & $9(6.2)$ \\
\hline
\end{tabular}

VAP ventilator-associated pneumonia

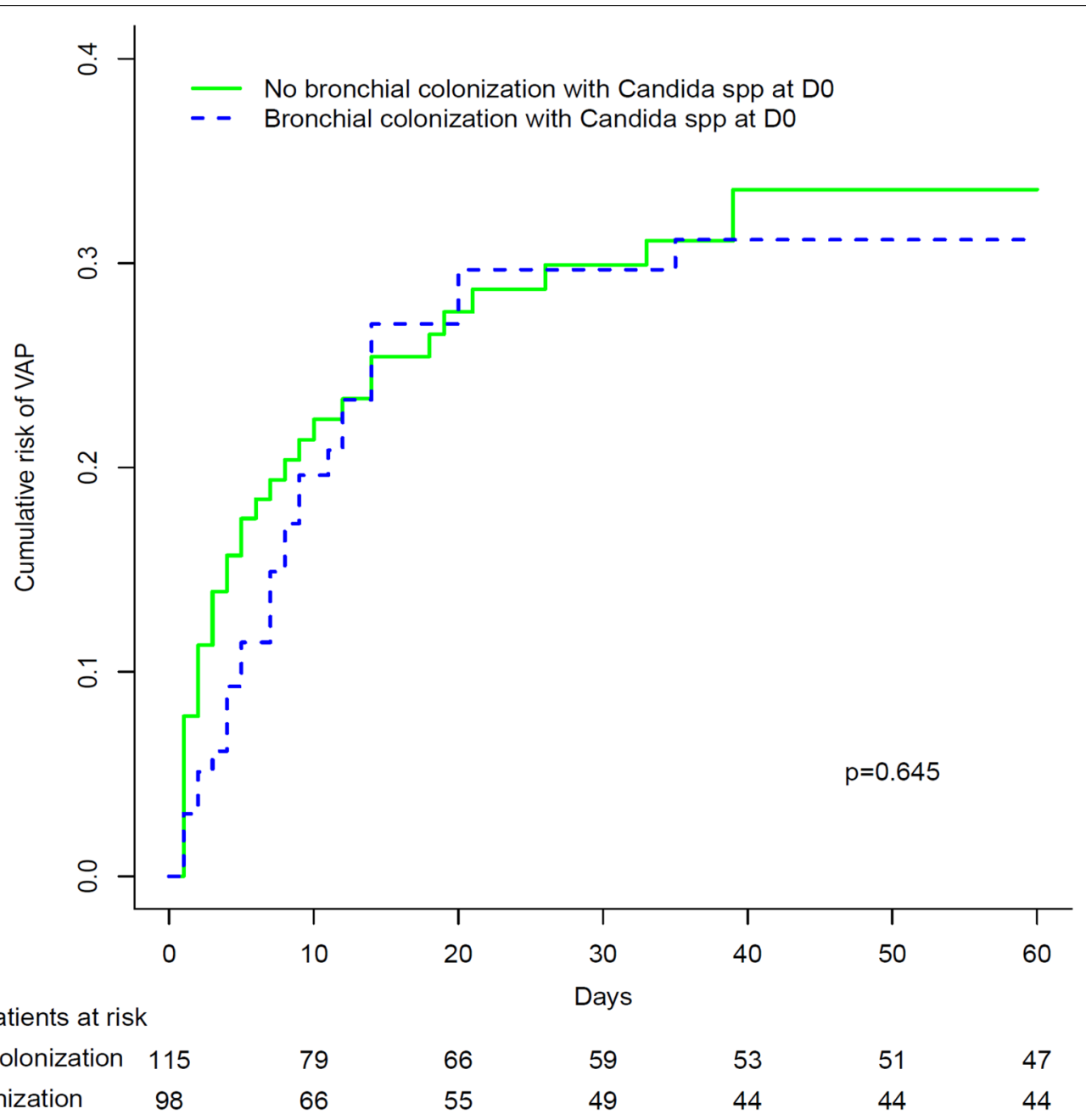

Fig. 3 Cumulative risk of ventilator-associated pneumonia according to Candida spp. bronchial colonization at D0 
Table 3 Results of the final steps of the cause-specific models

\begin{tabular}{|c|c|c|c|c|c|c|c|c|}
\hline \multirow[t]{2}{*}{ Parameter } & \multicolumn{4}{|l|}{ VAP } & \multicolumn{4}{|c|}{ ICU discharge } \\
\hline & CSHR & \multicolumn{2}{|l|}{$95 \% \mathrm{Cl}$} & $p$ value & CSHR & \multicolumn{2}{|l|}{$95 \% \mathrm{Cl}$} & $p$ value \\
\hline \multicolumn{6}{|c|}{ Model 1 adjusted for chronic respiratory diseases, case mix, creatinine, Procalcitonin, use of broad-spectrum $\beta$-lactams } & & & \\
\hline Candıda aırway colonizatıon (tıme-dependent) & 0.91 & 0.60 & 1.60 & 0.91 & 1.41 & 0.93 & 2.14 & 0.11 \\
\hline \multicolumn{9}{|c|}{$\begin{array}{l}\text { Model } 2 \text { adjusted for chronic respiratory diseases, case mix, creatinine, Procalcitonin, use of broad-spectrum } \beta \text {-lactams and markers of immune } \\
\text { paralysis }\end{array}$} \\
\hline Candida airway colonization (time-dependent) & 0.98 & 0.60 & 1.60 & 0.91 & 1.45 & 0.93 & 2.14 & 0.11 \\
\hline mHLA-DR $\leq 8000$ (time-dependent) & 1.06 & 0.60 & 1.87 & 0.85 & 0.81 & 0.52 & 1.27 & 0.35 \\
\hline Lymphocytes Giga/l> 1 (time-dependent) & 0.80 & 0.44 & 1.43 & 0.45 & 0.76 & 0.48 & 1.20 & 0.24 \\
\hline Neutrophils-lymphocyte ratio > 10 (time-dependent) & 0.64 & 0.35 & 1.14 & 0.13 & 0.93 & 0.59 & 1.46 & 0.75 \\
\hline
\end{tabular}

VAP ventilator-associated pneumonia, CSHR cause-specific hazard ratio, $m H L A-D R$ monocyte human leukocyte antigen-DR isotype

than previously considered. Both species can sense and respond to the diverse diffusible signaling molecules produced in the niches where they coexist. The interaction between fungi and bacteria could lead to increased toxin production and increased host damage and inflammation [32].

Secondly, intratracheal instillation of live Candida spp. in rats can trigger the host inflammatory response, alter the lung innate immune response, and favor the development of experimental $P$. aeruginosa, S. aureus and Escherichia coli pneumonia [33]. On the contrary, in a murine model, Ader et al. reported that animals colonized by direct tracheal inoculation of live Candida spp. with a protocol designed to obtain Candida spp. colonization without epithelial injury were protected against $P$. aeruginosa pneumonia [34].

Most in vitro studies suggested that the interaction between Candida spp. and $P$. aeruginosa is likely to be antagonistic [34, 35]. C. albicans and P. aeruginosa are able to interact either directly, by contact, toxin-induced killing, or by the inhibition of virulence factors [32].

In addition, in a cohort study, the use of nebulized amphotericin B in mechanically ventilated patients with Candida spp. airway colonization had no impact on the incidence rate of VAP or on ICU mortality despite increasing the rate of Candida spp. decolonization [13]. Similarly, micafungin therapy of patients with multiple Candida spp. colonization, multiple organ failure and new sepsis of unknown etiology did not result in a decrease of VAP incidence as compared to placebo [10].

This study has some limitations. The local immune system is important for pulmonary clearance of microorganisms, but was not assessed. Indeed, the local presence of granulocyte/macrophage colony-stimulating factor in the lung apparently decreases endotoxin tolerance and may partly protect the lung from local immune suppression [36] and direct Candida-related insult [6].
Second, we recruited/enrolled a population of very severely ill patients with profound immunoparalysis. Whether our results can be extrapolated to less severely ill patients is therefore questionable. Third, the small number of cases of Staphylococcus aureus VAP and $P$. aeruginosa VAP jeopardizes the reliability of the sensitivity analyses.

\section{Conclusion}

In a prospective study, Candida spp. airway colonization was not associated with an increase in the risk of VAP even when immune status was taken into account.

\section{Electronic supplementary material}

The online version of this article (https://doi.org/10.1007/s00134-019-05622-0) contains supplementary material, which is available to authorized users.

\section{Author details}

${ }^{1}$ Medical and Infectious Diseases ICU, Bichat-Claude Bernard Hospital, APHP, Paris, France. ${ }^{2}$ INSERM, IAME UMR 1137, Paris-Diderot Sorbonne-Paris Cité University, Paris, France. ${ }^{3}$ Medical ICU, Albert Michallon University Hospital, Grenoble, France. ${ }^{4}$ OUTCOMEREA Network, Aulnay Sous Bois, France. ${ }^{5}$ Univ. Grenoble Alpes, CNRS, CHU Grenoble Alpes, Grenoble INP, TIMC-IMAG, 38000 Grenoble, France. ${ }^{6}$ Institute of Engineering, Univ. Grenoble Alpes, Grenoble, France. ${ }^{7}$ Laboratoire de Parasitologie-Mycologie, CHU ClermontFerrand, CNRS, Université Clermont Auvergne, 63000 Clermont-Ferrand, France. ${ }^{8}$ Université Clermont Auvergne, UMR CNRS 6023, Clermont-Ferrand, France. ${ }^{9}$ Department of Immunology, Grenoble-Alpes University Hospital (CHUGA) 38700 Grenoble, France. ${ }^{10}$ INSERM U1209, CNRS UMR 5309, Institute for Advanced Biosciences "Université Grenoble Alpes, 38700 Grenoble, France. ${ }^{11}$ Medical ICU, Gabriel-Montpied University Hospital, Clermont-Ferrand, France.

\section{Compliance with ethical standards}

\section{Conflicts of interest}

The authors declare that they have no conflict of interest.

\section{Ethical standards}

The study was sponsored by the University of Grenoble and received grant funding from the French Ministry of Health (ethics committee: ("Comite de Protection des Personnes") CPP South East IV 11-055 August 30th 2011—No. ID RCB 2011-A00767-34; www.clinicaltrials.gov: NCT01770015). 


\section{Informed consent}

Written informed consent was obtained from all participants or their proxies. In situations of impaired decision-making capacity and absence of surrogates, informed consent was obtained later on from the patient (in compliance with French laws).

\section{Publisher's Note}

Springer Nature remains neutral with regard to jurisdictional claims in published maps and institutional affiliations.

Received: 28 December 2018 Accepted: 13 April 2019

Published online: 24 April 2019

\section{References}

1. Hamet M, Pavon A, Dalle F, Pechinot A, Prin S, Quenot JP, Charles PE (2012) Candida spp. airway colonization could promote antibioticresistant bacteria selection in patients with suspected ventilator-associated pneumonia. Intensive Care Med 38:1272-1279

2. Williamson DR, Albert M, Perreault MM, Delisle MS, Muscedere J, Rotstein C, Jiang X, Heyland DK (2011) The relationship between Candida species cultured from the respiratory tract and systemic inflammation in critically ill patients with ventilator-associated pneumonia. Can J Anaesth J Can D'Anesth 58:275-284

3. Delisle MS, Williamson DR, Perreault MM, Albert M, Jiang X, Heyland DK (2008) The clinical significance of Candida colonization of respiratory tract secretions in critically ill patients. J Crit Care 23:11-17

4. Heyland D, Jiang X, Day AG, Laverdiere M (2011) Serum beta-d-glucan of critically ill patients with suspected ventilator-associated pneumonia: preliminary observations. J Crit Care 26:536 e531-536 e539

5. Petri MG, Konig J, Moecke HP, Gramm HJ, Barkow H, Kujath P, Dennhart R, Schafer H, Meyer N, Kalmar P, Thulig P, Muller J, Lode H (1997) Epidemiology of invasive mycosis in ICU patients: a prospective multicenter study in 435 non-neutropenic patients. Paul-Ehrlich Society for Chemotherapy, Divisions of Mycology and Pneumonia Research. Intensive Care Med 23:317-325

6. Meersseman W, Lagrou K, Spriet I, Maertens J, Verbeken E, Peetermans WE, Van Wijngaerden E (2009) Significance of the isolation of Candida species from airway samples in critically ill patients: a prospective, autopsy study. Intensive Care Med 35:1526-1531

7. Chastre J, Fagon JY (2002) Ventilator-associated pneumonia. Am J Respir Crit Care Med 165:867-903

8. El-Ebiary M, Torres A, Fabregas N, de la Bellacasa JP, Gonzalez J, Ramirez $J$, del Bano D, Hernandez C, Jimenez de Anta MT (1997) Significance of the isolation of Candida species from respiratory samples in critically ill, non-neutropenic patients. An immediate postmortem histologic study. Am J Respir Crit Care Med 156:583-590

9. Rello J, Esandi ME, Diaz E, Mariscal D, Gallego M, Valles J (1998) The role of Candida sp isolated from bronchoscopic samples in nonneutropenic patients. Chest 114:146-149

10. Timsit JF, Azoulay E, Schwebel C, Charles PE, Cornet M, Souweine B, Klouche K, Jaber S, Trouillet JL, Bruneel F, Argaud L, Cousson J, Meziani F, Gruson D, Paris A, Darmon M, Garrouste-Orgeas M, Navellou JC, Foucrier A, Allaouchiche B, Das V, Gangneux JP, Ruckly S, Maubon D, Jullien $\checkmark$, Wolff M (2016) Empirical micafungin treatment and survival without invasive fungal infection in adults with ICU-acquired sepsis, Candida colonization, and multiple organ failure: the EMPIRICUS randomized clinical trial. JAMA 316:1555-1564

11. Azoulay E, Timsit JF, Tafflet M, de Lassence A, Darmon M, Zahar JR, Adrie C, Garrouste-Orgeas M, Cohen Y, Mourvillier B, Schlemmer B (2006) Candida colonization of the respiratory tract and subsequent pseudomonas ventilator-associated pneumonia. Chest 129:110-117

12. Nseir S, Jozefowicz E, Cavestri B, Sendid B, Di Pompeo C, Dewavrin F, Favory R, Roussel-Delvallez M, Durocher A (2007) Impact of antifungal treatment on Candida-Pseudomonas interaction: a preliminary retrospective case-control study. Intensive Care Med 33:137-142

13. Ong DS, Klein Klouwenberg PM, Spitoni C, Bonten MJ, Cremer OL (2013) Nebulised amphotericin B to eradicate Candida colonisation from the respiratory tract in critically ill patients receiving selective digestive decontamination: a cohort study. Crit Care 17:R233

14. Albert M, Williamson D, Muscedere J, Lauzier F, Rotstein C, Kanji S, Jiang X, Hall M, Heyland D (2014) Candida in the respiratory tract secretions of critically ill patients and the impact of antifungal treatment: a randomized placebo controlled pilot trial (CANTREAT study). Intensive Care Med 40:1313-1322

15. Landelle C, Lepape A, Voirin N, Tognet E, Venet F, Bohe J, Vanhems P, Monneret G (2010) Low monocyte human leukocyte antigen-DR is independently associated with nosocomial infections after septic shock. Intensive Care Med 36:1859-1866

16. Hotchkiss RS, Monneret G, Payen D (2013) Sepsis-induced immunosuppression: from cellular dysfunctions to immunotherapy. Nat Rev Immunol 13:862-874

17. Jabra-Rizk MA, Kong EF, Tsui C, Nguyen MH, Clancy CJ, Fidel PL Jr, Noverr M (2016) Candida albicans pathogenesis: fitting within the hostmicrobe damage response framework. Infect Immun 84:2724-2739

18. Desai JV, van de Veerdonk FL, Lionakis MS (2018) Understanding the role of host immune responses in invasive candidiasis. Intensive Care Med 44:1310-1314

19. Demaret J, Walencik A, Jacob MC, Timsit JF, Venet F, Lepape A, Monneret $\mathrm{G}$ (2013) Inter-laboratory assessment of flow cytometric monocyte HLA-DR expression in clinical samples. Cytom Part B, Clin Cytom 84:59-62

20. Riche F, Gayat E, Barthelemy R, Le Dorze M, Mateo J, Payen D (2015) Reversal of neutrophil-to-lymphocyte count ratio in early versus late death from septic shock. Crit Care 19:439

21. Adrie C, Lugosi M, Sonneville R, Souweine B, Ruckly S, Cartier JC, Garrouste-Orgeas M, Schwebel C, Timsit JF (2017) Persistent lymphopenia is a risk factor for ICU-acquired infections and for death in ICU patients with sustained hypotension at admission. Ann Intensive care 7:30

22. Bailly S, Maubon D, Fournier P, Pelloux H, Schwebel C, Chapuis C, Foroni L, Cornet M, Timsit JF (2016) Impact of antifungal prescription on relative distribution and susceptibility of Candida spp.--Trends over 10 years. J Infect 72:103-111

23. Ibn Saied W, Souweine B, Garrouste-Orgeas M, Ruckly S, Darmon M, Bailly S, Cohen Y, Azoulay E, Schwebel C, Radjou A, Kallel H, Adrie C, Dumenil AS, Argaud L, Marcotte G, Jamali S, Papazian L, GoldgranToledano D, Bouadma L, Timsit JF (2017) Respective impact of implementation of prevention strategies, colonization with multiresistant bacteria and antimicrobial use on the risk of early-and late-onset VAP: an analysis of the OUTCOMEREA network. PLoS One 12:e0187791

24. Monneret G, Venet F, Kullberg BJ, Netea MG (2011) ICU-acquired immunosuppression and the risk for secondary fungal infections. Med Mycol 49(Suppl 1):S17-S23

25. Romani L (2011) Immunity to fungal infections. Nat Rev Immunol 11:275-288

26. Venet F, Monneret G (2018) Advances in the understanding and treatment of sepsis-induced immunosuppression. Nat Rev Nephrol 14:121-137

27. Cheron A, Floccard B, Allaouchiche B, Guignant C, Poitevin F, Malcus C, Crozon J, Faure A, Guillaume C, Marcotte G, Vulliez A, Monneuse O, Monneret G (2010) Lack of recovery in monocyte human leukocyte antigen-DR expression is independently associated with the development of sepsis after major trauma. Crit Care 14:R208

28. Venet F, Chung CS, Monneret G, Huang X, Horner B, Garber M, Ayala A (2008) Regulatory T cell populations in sepsis and trauma. J Leukoc Biol 83.523-535

29. Azoulay E, Cohen Y, Zahar JR, Garrouste-Orgeas M, Adrie C, Moine $P$, de Lassence A, Timsit JF (2004) Practices in non-neutropenic ICU patients with Candida-positive airway specimens. Intensive Care Med 30:1384-1389

30. Tan X, Zhu S, Yan D, Chen W, Chen R, Zou J, Yan J, Zhang X, Farmakiotis D, Mylonakis E (2016) Candida spp. airway colonization: a potential risk factor for Acinetobacter baumannii ventilator-associated pneumonia. Med Mycol 54:557-566

31. Panpetch W, Somboonna N, Bulan DE, Issara-Amphorn J, Finkelman M, Worasilchai N, Chindamporn A, Palaga T, Tumwasorn S, Leelahavanichkul A (2017) Oral administration of live-or heat-killed Candida albicans worsened cecal ligation and puncture sepsis in a murine model 
possibly due to an increased serum (1->3)-beta-D-glucan. PLoS One 12:e0181439

32. Morales DK, Hogan DA (2010) Candida albicans interactions with bacteria in the context of human health and disease. PLoS Pathog 6:e1000886

33. Roux D, Gaudry S, Khoy-Ear L, Aloulou M, Phillips-Houlbracq M, Bex J, Skurnik D, Denamur E, Monteiro RC, Dreyfuss D, Ricard JD (2013) Airway fungal colonization compromises the immune system allowing bacterial pneumonia to prevail. Crit Care Med 41:e191-e199
34. Ader F, Jawhara S, Nseir S, Kipnis E, Faure K, Vuotto F, Chemani C, Sendid B, Poulain D, Guery B (2011) Short term Candida albicans colonization reduces Pseudomonas aeruginosa-related lung injury and bacterial burden in a murine model. Crit Care 15:R150

35. Hogan DA, Kolter R (2002) Pseudomonas-Candida interactions: an ecological role for virulence factors. Science 296:2229-2232

36. Cavaillon JM, Annane D (2006) Compartmentalization of the inflammatory response in sepsis and SIRS. J Endotoxin Res 12:151-170 